ORIGINAL ARTICLE

\title{
Transferability of heterologous primers in Brycon falcatus
}

\author{
Diego dos Santos PENHA ${ }^{1}$, Felipe Pinheiro de SOUZA¹, Ed Christian Suzuki de LIMA ${ }^{1}$, \\ Angela Maria URREA-ROJAS ${ }^{1}$, Victor César Freitas PANDOLFI ${ }^{1}$, Andrei Lincoln YAMACHITA ${ }^{1}$, \\ Jayme Aparecido POVH ${ }^{2}$, Natalia Gonçalves LEITE ${ }^{1}$, Ulisses de Pádua PEREIRA ${ }^{1}$, \\ Nelson Mauricio LOPERA-BARRERO ${ }^{1^{*} \text { (B) }}$ \\ 1 Universidade Estadual de Londrina (UEL), Programa de Pós-Graduação em Ciência Animal, Londrina, PR, Brazil \\ 2 Universidade Federal de Mato Grosso do Sul (UFMS), Faculdade de Medicina Veterinária e Zootecnia, Campo Grande, MS, Brasil \\ * Corresponding author: nmlopera@uel.br; (DD https://orcid.org/0000-0002-7154-5134; \\ (D) https://orcid.org/0000-0003-3315-018X
}

\begin{abstract}
The genus Brycon comprises fish species of significant socioeconomic and biological importance in Brazil. Despite that, the genetic knowledge about these species is scarce, especially regarding Brycon falcatus. Thus, the objective of this study was to evaluate the transferability of heterologous microsatellite primers in $B$. falcatus for the first time. Heterologous primers obtained from B. opalinus, B. hilarii, B. insignis, B. orbignyanus, B. amazonicus, Prochilodus argenteus, Prochilodus lineatus, Piaractus mesopotamicus, and Colossoma macropomum were evaluated. The primers that showed the best amplification patterns were applied to a sample of 22 individuals and the genetic parameters were calculated. Nine primers displayed satisfactory cross-amplification with B. falcatus: BoM5 (Brycon opalinus); Bh8, Bh13 and Bh16 (B. hilarii); Borg59 (B. orbignyanus); Bag22 (B. amazonicus); Par12 and Par80 (P. argenteus), and Cm1A8 (C. macropomum). The genetic parameters (number of alleles, effective alleles, allele richness, and expected and observed heterozygosity) and the polymorphic information content (PIC) confirmed the viability of these primers for population genetics analyses. Our study demonstrates the potential of transferability of microsatellite markers from related species and even different genera to $B$. falcatus, providing usefull tools for future population genetic studies in this species.
\end{abstract}

KEYWORDS: Bryconidae, cross amplification, genetic conservation, genetic variability, SSR

\section{Transferibilidade de primers heterólogos em Brycon falcatus}

\section{RESUMO}

O gênero Brycon compreende um grupo de espécies de peixes de grande importância socioeconômica e biológica no Brasil. Entretanto, o conhecimento genético dessas espécies é escasso, principalmente no caso do Brycon falcatus. Diante disso, objetivouse verificar a transferibilidade de primers heterólogos em $B$. falcatus. Foram avaliados primers heterólogos provenientes das espécies B. opalinus, B. hilarii, B. insignis, B. orbignyanus, B. amazonicus, Prochilodus argenteus, Prochilodus lineatus, Piaractus mesopotamicus e Colossoma macropomum. Os primers que demonstraram melhores padróes de amplificação foram aplicados a uma amostra de 22 indivíduos e os parâmetros genéticos foram calculados. Nove primers apresentaram resultados satisfatórios de amplificação cruzada com B. falcatus: BoM5 (Brycon opalinus), Bh8, Bh13 e Bh16 (B. hilarii); Borg59 (Brycon orbignyanus); Bag22 (B. amazonicus); Par12 and Par80 (Prochilodus argenteus) e Cm1A8 (Colossoma macropomum). Os parâmetros genéticos (número de alelos, alelos efetivos, riqueza de alelos e heterozigosidade esperada e observada) e o conteúdo de informação polimórfica (PIC) demonstraram a viabilidade da utilização dos primers para análises genéticas populacionais. Nosso estudo demonstra o potencial de transferibilidade de marcadores microssatélites de espécies relacionadas e até de gêneros diferentes para B. falcatus, fornecendo ferramentas úteis para futuros estudos genéticos populacionais nessa espécie.

PALAVRAS-CHAVE: Bryconidae, amplificação cruzada, conservação genética, variabilidade genética, SSR 


\section{INTRODUCTION}

The Neotropical region has the largest number of freshwater fish species in the world, with fish of the order Characiformes standing out for the vast diversity of species, many not yet described (Guisande et al. 2012; Ota et al. 2015). Within this order, the genus Brycon (Müller \& Troschel, 1844) is considered one of the main neotropical freshwater fish (Antunes et al. 2010). It has a wide geographic distribution, occurring in the Amazonas, Paraná, Paraguai, Orinoco, Magdalena, and Tocantins-Araguaia river basins (Howes, 1982; Antunes et al. 2010). Brycon species are medium to large sized, live in small shoals, have omnivorous feeding habits (Lima and Castro 2000), and perform fairly extensive reproductive migrations (Goulding 1980). These fish are mostly used for sport fishing and human consumption (Lima 2017).

Brycon falcatus (Muller and Troschel, 1844), regionally known in Brazil as matrinxã miúda or voadeira, is highlighted within Brycon (Bini 2012) because it is a highly consumed species and has great commercial importance in sport and artisanal fishing (Matos et al. 2018). It is broadly distributed in the Amazon basin, also occurring in the AraguaiaTocantins River basin (Antunes et al. 2010; Isaac et al. 2015; Matos et al. 2018). Its rich fish fauna in these basins makes Brycon an important exploitable resource, but information on the biological, biogeographical, ecological, and genetic characteristics of its species are generally scarce, especially for B. falcatus.

Microsatellites are promising molecular markers to generate genetic information for $B$. falcatus, since they allow to access important genetic information such as population genetic structure, demographic history, kinship and mating system. The most important characteristics of microsatellites are high polymorphism, marker co-dominance and relative abundance with uniform genome coverage (Gasques et al. 2013; Abdul-Muneer 2014). One of the main limitations of using microsatellite markers is the need for species-specific primers. However, pairs of primers designed for one species can be used for cross-amplification in phylogenetically related species, allowing genetic studies to use transferred markers or heterologous primers, which help to save time and money (Abdul-Muneer 2014; Castro et al. 2017; Lopera-Barrero et al. 2016a).

Accordingly, the objective of this study was to evaluate, for the first time, the transferability of heterologous primers from Brycon opalinus (Cuvier, 1819), B. hilarii (Valenciennes, 1850), B. insignis (Steindachner, 1877), B. orbignyanus (Valenciennes, 1850), B. amazonicus (Spix \& Agassiz, 1829), Prochilodus argenteus (Agassiz, 1829), P. lineatus (Valenciennes, 1836), Piaractus mesopotamicus (Holmberg, 1887), and Colossoma macropomum (Cuvier, 1818) to B. falcatus.

\section{MATERIAL AND METHODS}

Caudal fin fragments (approximately $0.5 \mathrm{~cm}^{2}$ ) were collected from 22 wild Brycon falcatus individuals sampled in the Araguaia River (15 $53^{\prime} 21.52^{\prime \prime}$ S, 52 $\left.2^{\circ} 14^{\prime} 47.79^{\prime \prime W}\right)$, near the municipality of Barra das Garças, state of Mato Grosso, Brazil. The samples were preserved in 70\% alcohol for subsequent analysis in the laboratory. This study was approved by the ethics committee in the use of animals of Universidade Estadual de Londrina (CEUA-UEL \# 21383.2017.93).

DNA extraction followed the methodology described by Lopera-Barrero et al (2008). The DNA concentration was evaluated in a spectrophotometer SLIPQ 026 - L-Quant Quantifier (Loccus Biotecnologia, Ribeirão Preto, Brazil), and the samples were diluted to a concentration of $30 \mathrm{ng} \mu \mathrm{L}^{-1}$. DNA integrity was assessed on $1 \%$ agarose gel stained with SYBR Safe DNA (Invitrogen). Electrophoresis was performed in $0.5 \mathrm{X}$ TBE buffer $(250 \mathrm{mM}$ Tris- $\mathrm{HCl}, 30 \mathrm{mM}$ boric acid, and $41.5 \mathrm{mM}$ EDTA) for one hour at $70 \mathrm{~V}$. The gel was observed using a trans-illuminator and the image was captured by a photo-documentation system. Analyzes were performed at the Aquaculture and Genetics Research Center (NEPAG) of Universidade Estadual de Londrina (UEL).

Thirty-five primers were tested, of which seventeen belonged to Brycon: two were described by Barroso et al. (2005) for B. opalinus (BoM5 and BoM13), five were described by Sanches and Galetti (2006) for B. hilarii (Bh5, Bh6, Bh8, Bh13, Bh16), one was described by Matsumoto and Hilsdorf (2009) for B. insignis (Bc48-10), three were described by Souza et al. (2018a) for B. orbignyanus (Borg13, Borg25, and Borg59), and six were described by Araújo (2012) for B. amazonicus (Bag22, Bag25, Bag27, Bag31, Bam6, and Bam11). Additionally, we tested primers of related species: five described by Barbosa et al. (2006) (Par12, Par14, Par15, Par21, and Par43) and two described by Barbosa et al. (2008) (Par80, and Par82) for Prochilodus argenteus, one described by Yazbeck and Kalapothakis (2007) for Prochilodus lineatus (Pli30), five described by Calcagnotto et al. (2001) for Piaractus mesopotamicus (Pme2, Pme4, Pme5, Pme20, and Pme28) and five described by Santos et al. (2009) for Colossoma macropomum (Cm1A8, Cm1A11, Cm1C8, Cm1D1, and Cm1E3).

The DNA was amplified in a $15-\mu \mathrm{L}$ reaction volume with $1 \mathrm{X}$ Tris- $\mathrm{KCl}$ buffer, $2.0 \mathrm{mmol} \mathrm{L}^{-1}$ of $\mathrm{MgCl}_{2}, 0.4 \mu \mathrm{mol}$ $\mathrm{L}^{-1}$ of each primer (Forward and Reverse), $0.2 \mathrm{mmol} \mathrm{L}^{-1}$ dNTP, 1U Platinum Taq DNA Polymerase, and $30 \mathrm{ng}$ of the target DNA. A PCR was performed under the following conditions: initial denaturation at $94^{\circ} \mathrm{C}$ during four minutes, followed by 35 cycles of denaturation at $94^{\circ} \mathrm{C}$ during 30 seconds, annealing (primer-depedent temperature) during 30 seconds, and extension at $72{ }^{\circ} \mathrm{C}$ during one minute, and a final extension at $72^{\circ} \mathrm{C}$ during 10 minutes. Three different anneling temperatures were tested for each primer: the specific 
temperature for each primer (described by the authors), $2{ }^{\circ} \mathrm{C}$ below and $2{ }^{\circ} \mathrm{C}$ above the specific temperatures. The temperature that generated the best banding pattern was selected for use in the population analysis (Table 1). The amplified samples were run using $10 \%$ polyacrylamide gel electrophoresis (acrylamide:bisacrylamide ratio of 29:1), 6 $\mathrm{M}$ urea, in $0.5 \mathrm{X}$ TBE buffer at $180 \mathrm{~V}$ and $250 \mathrm{~mA}$ for eight hours. The methodology proposed by Bassam et al. (1991) was followed in gel staining, with modifications. The gel was immersed in a fixation solution (10\% ethanol and $0.5 \%$ acetic acid) for 20 minutes, and then in $6 \mathrm{mM}$ silver nitrate solution for 30 minutes, and revealed in solution with $0.75 \mathrm{M} \mathrm{NaOH}$ and $0.22 \%$ of $40 \%$ formaldehyde, then was photographed for later analysis.

Initially, six B. falcatus DNA samples were amplified for each primer for an initial quality assessment and selection of the best annealing temperature. Primers that presented an adequate band pattern, i.e., a clear pattern and no nonspecific bands, were selected for the next step. The primers with good transferability in the initial test were used in 22 specimens of $B$. falcatus following the same methodology described previously, and genetic parameters were calculated. The number of alleles $(\mathrm{Na})$, effective number of alleles $(\mathrm{Ne})$, observed heterozygosity (Ho), expected heterozygosity (He), and the Hardy-Weinberg equilibrium $(\mathrm{Hw})$ were calculated for each locus using the GenAlex software version 6.5, according to Peakall and Smouse (2012). The coefficient of inbreeding $\left(\mathrm{F}_{\mathrm{IS}}\right)$, the allelic richness $(\mathrm{Ra})$ and allelic frequencies were calculated for each locus using FSTAT software (Goudet 2005). The polymorphic information content (PIC) was analyzed using the software Cervus 3.0.7 (Kalinowski et al. 2007). The PIC classification was performed according to Botstein et al. (1980) considering

Table 1. Characterization of each heterologous locus of microsatellite primers tested for Brycon falcatus. $T A^{\circ} \mathrm{C}=$ annealing temperature; $\mathrm{PIC}=$ polymorphic information content; Di-: dinucleotide; Tri-: trinucleotide; $b p=$ base pairs.

\begin{tabular}{|c|c|c|c|c|c|c|c|}
\hline Locus & $\begin{array}{l}\text { Micro- } \\
\text { satellite } \\
\text { class }\end{array}$ & $\begin{array}{l}\text { Motif and } \\
\text { Repetition }\end{array}$ & Species & 5'-3'Sequence & $\begin{array}{l}\text { TA } \\
{ }^{\circ} \mathrm{C}\end{array}$ & $\begin{array}{l}\text { Fragment size - bp } \\
\text { (Frequency) }\end{array}$ & PIC \\
\hline \multirow{2}{*}{ Bh8 } & \multirow{2}{*}{ Tri- } & \multirow{2}{*}{$(\text { GAT })_{5}$} & \multirow{2}{*}{ Brycon hilarii } & F: CCATGGCTCAACACAGATAT & \multirow{2}{*}{54} & \multirow{2}{*}{$\begin{array}{c}190(0.182) ; 200 \\
(0.318) ; \\
215(0.500)\end{array}$} & \multirow{2}{*}{0.542} \\
\hline & & & & R:TGTACGAATCCTGAAATGCT & & & \\
\hline \multirow{2}{*}{ Bh13 } & \multirow{2}{*}{$\mathrm{Di}-$} & \multirow{2}{*}{$(\mathrm{AT})_{7}$} & \multirow{2}{*}{ Brycon hilarii } & F: AGCAATTTAAGCAAGTGAAG & \multirow{2}{*}{54} & \multirow{2}{*}{$\begin{array}{c}150(0.250) ; 165 \\
(0.750)\end{array}$} & \multirow{2}{*}{0.305} \\
\hline & & & & R: GCGTCGGAGCAGTAGTTATA & & & \\
\hline \multirow{2}{*}{ Bh16 } & \multirow{2}{*}{ Tri- } & \multirow{2}{*}{$(T A A)_{8}$} & \multirow{2}{*}{ Brycon hilarii } & F: CCTCCAATGAAAACAGTGCG & \multirow{2}{*}{58} & \multirow{2}{*}{$\begin{array}{c}145(0.182) ; 160 \\
(0.818)\end{array}$} & \multirow{2}{*}{0.253} \\
\hline & & & & R: ACGACTTAGCCACCCACCCT & & & \\
\hline \multirow{2}{*}{ BoM5 } & \multirow{2}{*}{ Complex } & $(A C)_{4} T(A C)_{10}$ & \multirow{2}{*}{ Brycon opalinus } & F: CGACCACAATAGGATTAGGG & \multirow{2}{*}{52} & \multirow{2}{*}{$\begin{array}{c}106(0.159) ; 110 \\
(0.114) ; \\
115(0.682) ; 150 \\
(0.045)\end{array}$} & \multirow{2}{*}{0.457} \\
\hline & & $\operatorname{AT}(A C)_{5}$ & & R: CTGGAGTTTGTGTGTGGA & & & \\
\hline \multirow{2}{*}{ Borg59 } & \multirow{2}{*}{ Complex } & $(\mathrm{CT})_{4} \mathrm{CC}(\mathrm{CT})_{5} \mathrm{TT}$ & \multirow{2}{*}{$\begin{array}{l}\text { Brycon } \\
\text { orbignyanus }\end{array}$} & F: TCCCTCTCTGTCCAAATGTCT & \multirow{2}{*}{55} & \multirow{2}{*}{$\begin{array}{c}225(0.050) ; 230 \\
(0.950)\end{array}$} & \multirow{2}{*}{0.090} \\
\hline & & $(\mathrm{CT})_{5}(\mathrm{CA})_{9}(\mathrm{CT})_{3} \mathrm{~N}(\mathrm{CT})_{7}$ & & R: GAAGTCAAGGTTAGAGCGGC & & & \\
\hline Bag22 & $\mathrm{Di}-$ & $(G A)_{14}$ & $\begin{array}{c}\text { Brycon } \\
\text { amazonicus }\end{array}$ & $\begin{array}{l}\text { F:TGTAGTAGTTCTGTCTGCTG } \\
\text { R:TGGAGTTGTTGGTGTGAATC }\end{array}$ & 61 & $\begin{array}{c}319(0.563) ; 376 \\
(0.438)\end{array}$ & 0.371 \\
\hline \multirow{2}{*}{ Par12 } & \multirow{2}{*}{ Tetra- } & \multirow{2}{*}{$(\mathrm{AAAC})_{7}$} & \multirow{2}{*}{$\begin{array}{l}\text { Prochilodus } \\
\text { argenteus }\end{array}$} & F: CGAGCTGGTACCGTCACATA & & $234(0.531) ; 244$ & \\
\hline & & & & R: AGCATGATGCAAAGGATCTG & 56 & $\begin{array}{c}(0.125) i \\
251(0.344)\end{array}$ & 0.505 \\
\hline R & Di & & Prochilodus & F: CTAACCTACAAACCTCATTC & & $190(0.154) ; 195$ & \\
\hline Parou & DI- & (CI) & argenteus & R: CTGTAAAAGCTCCACTTATC & 50 & $\begin{array}{c}(0.461) i \\
200(0.385)\end{array}$ & 0.535 \\
\hline $\mathrm{Cm} 1 \mathrm{~A} 8$ & Complex & $(\mathrm{CT})_{18}(\mathrm{CA})_{12}$ & $\begin{array}{l}\text { Colossoma } \\
\text { macropomum }\end{array}$ & $\begin{array}{l}\text { F: TGCTCTCCTGCAGTCTCTCA } \\
\text { R:TCATGGTTGCCACTCATCTC }\end{array}$ & 65 & $\begin{array}{c}170(0.045) ; 180 \\
(0.955)\end{array}$ & 0.083 \\
\hline
\end{tabular}


PIC values above 0.5 as very informative, between 0.25 and 0.50 as moderately informative, and below 0.25 as poorly informative. The presence of null alleles was determined using the software Micro-Checker 2.2.3 (Van Oosterhout et al. 2004).

\section{RESULTS}

Nine of the 35 primers tested showed a well-defined pattern of bands and polymorphism. The name of each cross-amplified primer and of the species for which it was originally developed are: BoM5 (Brycon opalinus), Bh8, Bh13, and Bh16 (B. hilarii), Borg59 (B. orbignyanus), Bag22 (B. amazonicus), Par80, and Par12 (Prochilodus argenteus), and Cm1A8 (Colossoma macropomum). The remaining primers were discarded, as they did not provide cross-amplification or were monomorphic (Supplementary Material, Table S1). Brycon species provided the most successful transferability, with five loci with satisfactory and reproducible results.

The size of the alleles ranged between $106 \mathrm{bp}$ (Bom5) and $376 \mathrm{bp}$ (Bag22) (Table 1). The primers that showed the highest number of alleles were BoM5 (four alleles); followed by Bh8, Par12 and Par80 (three alleles each); and Bh13, Bh16, Borg59, Bag22 and Cm1A8 (two alleles each) (Table 2).

The mean effective number of alleles was 1.934, ranging from 1.095 (Cm1A8) to 3.000 (Par12), which was smaller than the average number of alleles (2.556) (Table 2). This difference suggests the presence of rare or low-frequency alleles. Accordingly, three alleles had a frequency of less than 0.100 (BoM5: 150; Borg59: 225; Cm1A8: 170) and six alleles had a frequency between 0.100 and 0.200 (Bh8: 190; Bh16: 145; BoM5: 106 and 110; Par12: 244, and Par80: 190). Nevertheless, values of allelic richness were high and ranged from 1.838 (Cm1A8) to 3.830 (BoM5) (Table 2). The PIC values ranged between 0.083 (Cm1A8) and 0.542 (Bh8) (Table 1).

The expected heterozygosity $(\mathrm{He})$ surpassed the observed heterozygosity (Ho) in six (Bh8, Bh13, Bh16, BoM5, Par12 and Par80) of nine primers. The $\mathrm{p}$ value of $\mathrm{F}_{\text {IS }}$ was compared with alpha 0.05 after the adjusted nominal level of 0.0055 , and the result was positive and significant $(\mathrm{p}<0.05)$ in three loci (Bh8, BoM5, and Par80). The lowest and highest He value was found with primers Cm1A8 (0.087) and Bh8 (0.616), respectively (Table 2). A significant deviation in the HardyWeinberg equilibrium $(\mathrm{Hw})(\mathrm{P}<0.05)$ was observed with four primers (Bh8, BoM5, Bag22 and Par80), possibly influenced by the presence of null alleles in three of these primers (Bh8, BoM5 and Par80), which was confirmed through analysis by the Micro-Checker software 2.2.3.
Table 2. Number of alleles ( $\mathrm{Na})$, number of effective alleles ( $\mathrm{Ne}$ ), allele richness (Ra), observed heterozygosity (Ho), expected heterozygosity (He), Hardy-Weinberg equilibrium ( $p$ values) and inbreeding coefficient $\left(F_{15}\right)$ per microsatellite loci tested for Brycon falcatus.

\begin{tabular}{cccccccc}
\hline Locus & $\mathrm{Na}$ & $\mathrm{Ne}$ & $\mathrm{Ra}$ & $\mathrm{Ho}$ & $\mathrm{He}$ & $\begin{array}{c}\mathrm{Hw} \\
\text { (p value) }\end{array}$ & $\mathrm{F}_{15}$ \\
\hline Bh8 & 3.0 & 2.602 & 3.000 & 0.182 & 0.616 & $0.000^{*}$ & $0.716^{*}$ \\
Bh13 & 2.0 & 1.600 & 2.000 & 0.227 & 0.375 & $0.065^{\mathrm{ns}}$ & 0.413 \\
\hline Bh16 & 2.0 & 1.424 & 2.000 & 0.273 & 0.298 & $0.696^{\mathrm{ns}}$ & 0.106 \\
\hline BoM5 & 4.0 & 1.980 & 3.830 & 0.182 & 0.495 & $0.000^{*}$ & $0.646^{*}$ \\
\hline Borg59 & 2.0 & 1.105 & 1.883 & 0.100 & 0.095 & $0.814^{\mathrm{ns}}$ & -0.027 \\
\hline Bag22 & 2.0 & 2.0 & 3.0 & 0.875 & 0.492 & $0.002^{*}$ & -0.765 \\
\hline Par12 & 3.0 & 3.0 & 3.0 & 0.563 & 0.584 & $0.868^{\mathrm{ns}}$ & 0.069 \\
\hline Par80 & 3.0 & 2.600 & 3.000 & 0.154 & 0.615 & $0.002^{*}$ & $0.767^{*}$ \\
\hline Cm1A8 & 2.0 & 1.095 & 1.838 & 0.091 & 0.087 & $0.823^{\text {ns }}$ & -0.024 \\
\hline Mean & 2.556 & 1.934 & 2.616 & 0.294 & 0.406 & - & $0.303^{*}$ \\
\hline
\end{tabular}

ns: non-significant; *: significant at $p<0.05$

\section{DISCUSSION}

No previous studies have evaluated in detail the transferability of heterologous primers in B. falcatus. Here we demonstrate that the cross-amplification among species of Brycon is possible and applicable. Previous studies have shown that primers of B. opalinus and B. hilarii can be transferred to B. orbignyanus (Carmo et al. 2015; Castro et al. 2017). The possibility of cross-amplification of primers from two species of Salminus (S. brasiliensis and S. franciscanus) in B. orbignyanus was also reported (Carmo et al. 2015). The locus of P. argenteus (Par80) can also be used in B. orbignyanus (Castro et al. 2017). These previous studies confirm the plasticity of cross-amplification of microsatellites, even if they involve different genera. Our study corroborates these findings, as two loci of $P$. argenteus (Par12 and Par80) and one of $C$. macropomum (Cm1A8) displayed satisfactory amplification in B. falcatus. However, it is noteworthy that most validated loci belong to Brycon, which is expected due to the greater genetic proximity among species of the same genus.

The number of alleles per locus in most primers was similar to that found by Castro et al. (2017) in cross-amplification of microsatellite markers of $B$. hilarii and B. opalinus in $B$. orbignyans; and similar to that found by Souza et al. (2018b) in cross-amplification of microsatellite of B. hilarii, B. opalinus and $B$. orbignyanus in B. goudingi. In a study with natural populations of Prochilodus lineatus, Lopera-Barrero et al. (2016b) found a variation of three to six alleles produced by the Par 12 locus and three to five alleles produced by the Par80 locus. The number of alleles produced in our study was lower than that reported by Bignardi et al. (2016) for Brycon hilarii using the loci Bh8, Bh13, and Bh16. The same applies to the primers Par80 and Cm1A8, which showed a lower 
number of alleles than that found in the literature (Barbosa et al. 2008; Lopera-Barrero et al. 2016b; Santos et al. 2009). Based on the latter studies, we infer that the number of alleles per locus may vary, possibly due to factors, such as sample size, target species, effective size, etc. Although the number of alleles in our study was lower than in most referred studies, the mean observed (0.294) and expected (0.406) heterozygosity was similar to that found for some migratory fish like $B$. orbignyanus and Brycon gouldingi (Lima, 2004) (Ashikaga et al. 2015; Souza et al. 2018). In a study with wild populations of B. orbignyanus, Ashikaga et al. (2015) found $\mathrm{Ho}=0.233$ and $\mathrm{He}=0.497$ in a population in the Verde River, and Ho $=0.324$ and $\mathrm{He}=0.578$ in the Sucuriu River. In other rivers such as the Paranapanema and Uruguay, the populations had Ho $<0.2$ (Ashikaga et al. 2015). According to the authors, the Rio Verde population presented satisfactory genetic variability. A B. gouldingi population of the Araguaia River (Souza et al. 2018b) had lower Ho (0.157) and $\mathrm{He}(0.357)$ than those found for B. falcatus in our study. Our results demonstrate a moderate genetic variability in the $B$. falcatus population. However, the heterozygote deficit was notable through positive and significant values in the FIS index at the Bh8, BoM5, and Par80 loci. This heterozygous deficiency resulted in the Hardy-Weinberg equilibrium deviation in the same loci, possibly influenced by the presence of null alleles, which will be discussed below. Genetic analyzes of populations on a wider geographic scale will be necessary to estimate variability and the level of genetic structure in this species, and to evaluate the possibility of inbreeding in shoals, which would raise $\mathrm{F}_{\text {IS }}$ values.

The size of the alleles produced are close to the values reported by Bignardi et al. (2016) for B. hilarii. The primer Bag22 also produced a similar size to that found by Araújo (2012) for B. amazonicus. The size of the alleles reflects the number of repeating units in the microsatellite sequence. Therefore, because they share similar sizes, the Brycon species cited have similar sizes of short tandem repeats at the evaluated loci. However, care should be taken when establishing phylogenetic relationships, as the presence of homoplasia in regions with microsatellites may falsely infer kinship relationships, since in this condition alleles are identical by state, but not by ancestry (Turchetto-Zolet et al. 2017).

The allelic richness demonstrated that the heterologous primers were informative, which was corroborated by the PIC analysis, which yielded a high and moderately informative classification for seven of the nine heterologous primers tested (Bh8, Bh13, Bh16, BoM5, Bag22, Par12, and Par80). The higher the value, the greater is the ability of the marker to detect the variability between individuals (Preczenhak 2013).

The presence of null alleles in microsatellite markers is apparently recurrent in population studies in fish (Ashikaga et al., 2015; Henriques et al., 2017; Souza et al., 2018b).
Cross amplification in related species increases the frequency of these alleles as the phylogenetic distance between species increases (Chapuis and Estoup 2007). This has already been demonstrated in the transferability of B. orbignyanus, $B$. opalinus and $P$. argenteus microsatellite primers in $B$. gouldingi (Souza et al. 2018b), and B. opalinus primers in B. orbignyanus (Ashikaga et al. 2015). In the latter study, the authors attributed the deviation in the Hardy-Weinberg equilibrium in some loci of natural populations of $B$. orbignyanus to the high frequency of these alleles. Likewise, the presence of null alleles in our study is presumably the reason for the heterozygote deficiency and the deviation in the Hardy-Weinberg equilibrium for some loci (Bh8, BoM5 and Par80). This occurs because the presence of these alleles can cause heterozygous individuals to be mistakenly identified as homozygous for these loci, underestimating the levels of genetic diversity (Turchetto-Zolet et al. 2017). Our results and other studies cited, point to an important limitation in the use of these markers in related species, which strengthens the importance of developing specific microsatellite primers for $B$. falcatus. However, other studies should be conducted with more populations and larger sample size per population, to ascertain if the inbreeding, genetic bottlenecks, Wahnlund effect, null alleles, or a combination of these factors may be affecting the allelic frequencies of this population.

Closely related species have higher chances of amplification, and consequently more polymorphisms than phylogenetically distant species (Primmer et al. 1996), thus the knowledge of the phylogenetic relationships among species is important for the success of heterologous amplifications. Our results support this idea, as six of the nine primers that displayed satisfactory amplifications were derived from Brycon. Regarding the other three primers cross-amplified from Prochilodus and Colossoma, it is likely that flanking microsatellite regions were preserved during species differentiation, allowing the correct annealing of the primers in the corresponding regions. This hypothesis is reinforced by the fact that the primer Par80 had already been cross-amplified in another Brycon species, B. orbignyanus (Castro et al. 2017).

The transferability of heterologous primers is an important tool to reduces costs and time in developing species-specific primers. Genetic diversity indices and the polymorphic information content of the set of heterologous primers tested, demonstrate applicability in studies in natural or captive populations. Conservation of genetic variability in fish populations is critical for maintaining environmental adaptability (Frankham et al. 2008), and microsatellite markers are important tools for this assessment. In wild populations, microsatellite markers can be used to solve problems of taxonomic ambiguity, genetic structure and differentiation of isolated populations (Abdul-Muneer 2014). In addition, they can be used for restocking programs to control breeder mating and produce fingerlings with high 
genetic diversity (Bignardi et al. 2016). The breeding and genetic control of this species in captivity could reduce fishing pressure and the demand for wild individuals (Oliveira $e t$ al. 2018), contributing to the conservation of the species. In this case, these markers could assist in strategies that reduce genetic erosion and minimize the risks of inbreeding depression (Aguiar et al. 2013). We demonstrated, for the first time, that the cross-amplification of microsatellite primers of different species and genera in B. falcatus is possible and can provide valuable genetic information that may assist conservation and production of this species. Yet, in view of the occurrence of null alleles in some loci, we emphasize the concomitant need to develop specific microsatellite markers for B. falcatus.

\section{CONCLUSIONS}

The transferability of microsatellite markers of Brycon opalinus (BoM5), B. hilarii (Bh8, Bh13 and Bh16), B. orbignyanus (Borg59), B. amazonicus (Bag22), Prochilodus argenteus (Par12 and Par 80), and Colossoma macropomum (Cm1A8) were validated for B. falcatus. These results can enable future genetic evaluations with this species, which has scarcely been studied in Brazilian river basins.

\section{ACKNOWLEDGMENTS}

The authors would like to thank Conselho Nacional de Desenvolvimento Científico e Tecnológico (CNPq), Coordenação de Aperfeiçoamento de Pessoal de Nível Superior (CAPES), and the Programa de Pós-Graduação em Ciência Animal at Universidade Estadual de Londrina (UEL) for financial support.

\section{REFERENCES}

Abdul-Muneer, P.M. 2014. Application of microsatellite markers in conservation genetics and fisheries management: recent advances in population structure analysis and conservation strategies. Genetics Research International, 2014: 1-11.

Aguiar, J.; Schneider, H.; Gomes, F.; Carneiro, J.; Santos, S.; Rodrigues, L.R.; Sampaio, I. 2013. Genetic variation in native and farmed populations of Tambaqui (Colossoma macropomum) in the Brazilian Amazon: regional discrepancies in farming systems. Anais da Academia Brasileira de Ciências, 85: 1439-1447.

Antunes, R.S.P.; Gomes, V.N.; Prioli, S.M.A.P.; Prioli, R.A.; Júlio, H.F. Jr.; Prioli, L.M.; et al. 2010. Molecular characterization and phylogenetic relationships among species of the genus Brycon (Characiformes: Characidae) from four hydrographic basins in Brazil. Genetics and Molecular Research, 9: 674-684.

Araújo, G.T.C. 2012. Isolamento, caracterização de locus microssatélites e estimativa da variabilidade genética de Brycon amazonicus (Spix \& Agassiz, 1829) (Characidae: Bryconinae) em ambiente natural e cativeiro. Master's dissertation, Instituto Nacional de Pesquisas da Amazônia, Brazil, 95p. (https://bdtd. inpa.gov.br/handle/tede/1923). Accessed on 26 Jun 2020.
Ashikaga, F.Y.; Orsi, M.L.; Oliveira, C.; Senhorini, J.A.; Foresti, F.A. 2015. The endangered species Brycon orbignyanus: genetic analysis and definition of priority areas for conservation. Environmental Biology of Fishes, 98: 1845-1855.

Barbosa, A.C.D.R.; Corrêa, T.C.; Galzerani, F.; Galetti, P.M.; Hatanaka, T. 2006. Thirteen polymorphic microsatellite loci in the Neotropical fish Prochilodus argenteus (Characiformes, Prochilodontidae). Molecular Ecology Resources, 6: 936-938.

Barbosa, A.C.D.R.; Galzerani, F.; Corrêa, T.C.; Galetti, P.M.; Hatanaka, T. 2008. Description of novel microsatellite loci in the Neotropical fish Prochilodus argenteus and cross-amplifi cation in P. costatus and P. lineatus. Genetics and Molecular Biology, 31: 357-360.

Barroso, R.M.; Hilsdorf, A.W.S.; Moreira, H.L.M.; Mello, A.M.; Guimarães, S.E.F.; Cabello, P.H.; et al. 2005. Identification and characterization of microsatellites loci in Brycon opalinus (Cuvier, 1819) Characiforme, Characidae, Bryconiae. Molecular Ecology Notes, 1: 297-298.

Bassam, B.J.; Caetano-Anollés, G.; Gresshoff, P.M. 1991. Fast and sensitive silver staining of DNA in polyacrylamide gels. Analytical Biochemistry, 196: 80-83.

Bignardi, A.B.; Povh, J.A.; Alves, M.S.; Goes, E.S.R.; Corrêa, R.A.C.F; Castro, R.J.; et al. 2016. Genetic variability of Brycon hilarii in a repopulation program. Brazilian Archives of Biology and Technology, 59: 1-9.

Bini, E. 2012. Peixes do Brasil de Rios, Lagoas e Riachos. HomemPassaro Publicaçóes, Itapema, 300p.

Botstein, D.; White, R.L.; Skolmick, H.; Davis, R.W. 1980. Construction of a genetic linkage map in man using restriction fragment lenght polymorphisn. American Journal of Human Genetics, 32: 314-331.

Calcagnotto, D.; Russello, M.; DeSalle, R. 2001. Isolation and characterization of microsatellite loci in Piaractus mesopotamicus and their applicability in other Serrasalminae fish. Molecular Ecology Resources, 1: 245-247.

Carmo, F.M.S.; Polo, E.M.; Silva, M.A.; Yazbeck, G.M. 2015. Optimization of heterologous microsatellites in Piracanjuba. Pesquisa Agropecuária Brasileira, 50: 1236-1239.

Castro, P.L.; Ribeiro, R.P.; Santos, S.C.A.; Goes, E.S.R.; Souza, F.P.; Poveda-Parra, A.R.; et al. 2017. Cross-amplification of heterologous microsatellite markers in Piracanjuba. Ciência Rural, 47: 1-6.

Chapuis, M.P.; Estoup, A. 2007. Microsatellite null alleles and estimation of population differentiation. Molecular Biology and Evolution, 24: 621-631.

Frankham, R.; Ballou, J.D.; Briscoe, D.A. 2008. Fundamentos de Genética da Conservação. Sociedade Brasileira de Genética, Ribeirão Preto. 262p.

Gasques, L.S.; Beloni, K.P.; Oliveira, J.R. 2013. Os marcadores moleculares em peixes e suas aplicações em publicações da base de dados do Scielo. Arquivos de Ciências Veterinárias e Zoologia, 16: $47-50$

Goudet, J. 2005. FSTAT: a program to estimate and test Gene diversities and fixation indices (version 2.9.3.2). (https://www2. unil.ch/popgen/softwares/fstat.htm). Accessed on 12 Mar 2018. 
Goulding, M. 1980. The Fishes and the Forest: Explorations in Amazonian Natural History. University of California Press, Berkley, 280p.

Guisande, C.; Pelayo-Villamil, P.; Vera, M.; Manjarrés-Hernández, A.; Carvalho, M.R.; Vari, R.P.; et al. 2012. Ecological factors and diversification among Neotropical characiforms. International Journal of Ecology, 2012: 1-20.

Henriques, R.; Nielsen, E.S.; Durholtz, D.; Japp, D.; Von der Heyden, S. 2017. Genetic population sub-structuring of kingklip (Genypterus capensis - Ophidiidiae), a commercially exploited demersal fish off South Africa. Fisheries Research, 187: 86-95.

Howes, G. 1982. Review of the genus Brycon (Teleostei, Characoidei). Bulletin of the British Museum (Natural History). Zoology, 43: 1-47.

Isaac, V.J.; Almeida, M.C.; Cruz, R.E.A.; Nunes, L.G. 2015. Artisanal fisheries of the Xingu River basin in Brazilian Amazon. Brazilian Journal of Biology, 75: 125-137.

Kalinowski, S.T.; Taper, M.L.; Marshall, T.C. 2007. Revising how the computer program CERVUS accommodates genotyping error increases success in paternity assignment. Molecular Ecology, 16: 1099-1106.

Lima, F.C.T. 2017. A revision of the cis-andean species of the genus Brycon Müller \& Troschel (Characiformes: Characidae). Zootaxa, 4222: 1-189.

Lima, F.C.T.; Castro, R.M.C. 2000. Brycon vermelha, a new species of characid fish from the rio Mucuri, a coastal river of eastern Brazil (Ostariophysi, Characiformes). Ichthyological Exploration of Freshwaters, 11: 55-62.

Lopera-Barrero, N.M.; Povh, J.A.; Ribeiro, R.P.; Gomes, P.C.; Jacometo, C.B.; Lopes, T.S. 2008. Comparación de protocolos de extracción de $\mathrm{ADN}$ con muestras de aleta y larva de peces: extracción modificada con cloruro de sodio. Ciência $e$ Investigación Agraria, 35: 77-86.

Lopera-Barrero, N.M.; Santos, S.C.A.; Goes, E.S.R.; Castro, P.L.; Souza, F.P.; Poveda-Parra, A.R.; et al. 2016b. Monitoring and conservation genetics of Prochilodus lineatus wild populations of Pardo, Mogi Guaçu and Tiete rivers, São Paulo. Arquivo Brasileiro de Medicina Veterinária e Zootecnia, 68: 1621-1628.

Lopera-Barrero, N.M.; Tanamati, F.; Rodriguez-Rodriguez, M.D.P.; Povh, J.A.; Poveda-Parra, A.R.; Otonel R.A.A.; et al. 2016 a. Cross-amplification of heterologous microsatellite markers in Rhamdia quelen and Leporinus elongatus. Semina: Ciências Agrárias, 37: 517-524.

Matos, L.S.; Silva, J.O.S.; Kasper, D.; Carvalho, L.N. 2018. Assessment of mercury contamination in Brycon falcatus (Characiformes: Bryconidae) and human health risk by consumption of this fish from the Teles Pires River, Southern Amazonia. Neotropical Ichthyology, 16: 1-12.

Matsumoto, C.K.; Hilsdorf, A.W.S. 2009. Microsatellite variation and population genetic structure of a neotropical endangered Bryconinae species Brycon insignis Steindachner, 1877: implications for its conservation and sustainable management. Neotropical Ichthyology, 7: 395-402.

Oliveira, R.C.; Santos, M.D.C.F.; Bernardino, G.; Hrbek, T.; Farias, I.P. 2018. From river to farm: an evaluation of genetic diversity in wild and aquaculture stocks of Brycon amazonicus (Spix \&amp; Agassiz, 1829), Characidae, Bryconinae. Hydrobiologia, 805: 75-88.

Ota, R.R.; Message, H.J.; da Graça, W.J.; Pavanelli, C.S. 2015. Neotropical Siluriformes as a Model for Insights on Determining Biodiversity of Animal Groups. PloS ONE, 10: e0132913.

Peakall, R.; Smouse, P.E. 2012. GenAlEx 6.5: genetic analysis in Excel. Population genetic software for teaching and research - an update. Bioinformatics, 28: 2537-2539.

Preczenhak, A.P. 2013. Diversidade genética estimada por meio de marcadores moleculares e morfoagronômicos em acessos de mini tomate. Master's dissertation, Universidade Estadual do CentroOeste, Brazil, 67p.

Primmer, C.R.; Muller, A.P.; Ellegren, H. 1996. A wide-range survey of cross-species microsatellite. Molecular Ecology, 5: 365-378.

Sanches, A.; Galetti, J.R.P.M. 2006. Microsatellites loci isolated in the fresh water fish Brycon hilarii. Mololecular Ecology Notes, 6: 1045-1046.

Santos, M.D.C.F.; Hrbek, T.; Farias, I.P. 2009. Microsatellite markers for the tambaqui (Colossoma macropomum, Serrasalmidae, Characiformes), an economically important keystone species of the Amazon River floodplain. Molecular Ecology Resources, 9: 874-876.

Souza, F.P.D.; Lima, E.C.S.D.; Leite, N.G.; Urrea-Rojas, A.M.; Yamachita, A.L.; Pandolfi, V.C.F.; Lopera-Barrero, N.M. 2018b. Transferability of heterologous microsatellite primers in Brycon gouldingi. Ciência Rural, 48: e20180412.

Souza, F.P.; Urrea-Rojas, A.M.; Ruas, C.F.; Povh, J.A.; Ribeiro, R.P.; Ruas, E.A.; et al. 2018a. Novel microsatellite markers for the endangered neotropical fish Brycon orbignyanus and crossamplification in related species. Italian Journal of Animal Science, 17: 916-920.

Turchetto-Zolet, A.C.; Turchetto, C.; Zanella, C.M.; Passaia, G. 2017. Marcadores Moleculares na Era Genômica: Metodologias e Aplicaçôes. Sociedade Brasileira de Genética, Ribeirão Preto, $181 \mathrm{p}$.

Van Oosterhout, C.; Hutchinson, W.F.; Wills, D.P.M.; Shipley, P. 2004. Micro-Checker: Software for identifying and correcting genotyping errors in microsatellite data. Molecular Ecology Notes, 4: $535-538$.

Yazbeck, G.M.; Kalapothakis, E. 2007. Isolation and characterization of microsatellite DNA in the piracema fish Prochilodus lineatus (Characiformes). Genetics and Molecular Research, 6: 1026-1034.

RECEIVED: $14 / 11 / 2019$

ACCEPTED: 20/06/2020

ASSOCIATE EDITOR: Izeni P. Farias 
ACTA

AMAZONICA

PENHA et al. Transferability of heterologous primers to Brycon falcatus

SUPPLEMENTARY MATERIAL (only available in the electronic version)

PENHA et al. Transferability of heterologous primers to Brycon falcatus

Table S1. Species, locus and polymorphism evaluation in the amplification of the 35 microsatelitte primers tested in Brycon falcatus. M: monomorphic; P: polymorphic; $P^{*}$ : polymorphic with null allele $(P<0.05)$; -: absence of amplification or nonspecificity.

\begin{tabular}{|c|c|c|c|c|c|}
\hline Species & Locus & Amplification & Species & Locus & Amplification \\
\hline Brycon opalinus & BoM5 & $p^{*}$ & Prochilodus argenteus & Par12 & $P$ \\
\hline \multirow[t]{6}{*}{ Brycon hilarii } & BoM13 & M & & Par14 & - \\
\hline & Bh5 & - & & Par15 & - \\
\hline & Bh6 & - & & Par21 & - \\
\hline & Bh8 & $P^{*}$ & & Par43 & - \\
\hline & Bh13 & $P$ & & Par80 & $P^{*}$ \\
\hline & Bh16 & $P$ & & Par82 & - \\
\hline Brycon insignis & Bc48-10 & - & Prochilodus lineatus & Pli30 & - \\
\hline \multirow{4}{*}{ Brycon orbignyanus } & Borg13 & M & Piaractus mesopotamicus & Pme2 & - \\
\hline & Bora25 & M & & Pme4 & - \\
\hline & Bora50 & P & & Pme5 & - \\
\hline & & & & Pme20 & - \\
\hline \multirow{6}{*}{ Brycon amazonicus } & Bag 22 & $p *$ & & Pme28 & - \\
\hline & Bag25 & - & Colossoma macropomum & $\mathrm{Cm} 1 \mathrm{~A} 8$ & $P$ \\
\hline & Bag27 & M & & $\mathrm{Cm} 1 \mathrm{~A} 11$ & - \\
\hline & Bag31 & - & & $\mathrm{Cm} 1 \mathrm{C} 8$ & - \\
\hline & Bam6 & - & & Cm1D1 & - \\
\hline & Bam11 & - & & Cm1E3 & - \\
\hline
\end{tabular}

